\title{
Analysis on Energy Resources for the Development of Low Carbon Economy in Hebei Province
}

\author{
Ana Yin, Siyuan Deng \\ Shijiazhuang Economic College, \\ Shijiazhuang, China
}

\begin{abstract}
The industrial structure of Hebei Province is dominated by high energy consumption. In order to develop a low carbon economy, Hebei Province has the advantages of energy resources, but also the certain difficulty for energysaving and emission reduction. This paper analyzes the actuality of energy resources in Hebei Province and the existing problems, including nonrenewable energy resources and renewable energy resources, and put forward the countermeasures of developing low carbon economy in Hebei Province: to accelerate the pace of adjustment of industrial structure; vigorously promoting energy technologies and emission reduction technology innovation; improving the supporting policies; promoting the "low-carbon" mode, etc.
\end{abstract}

Keywords-energy resources; the low carbon economy; Hebei Province

\section{INTRODUCTION}

Hebei Province is rich in energy resources, it has considerable reserves in primary energy coal, oil and natural gas. Three oil fields (the North China, Jidong, Dagang) have proven the cumulative reserves of 2.7 billon T. An annual output of the crude oil in Hebei Province can reach to nearly 10 million tons and the natural gas is about 1 billon $\mathrm{m}^{3}$. Hebei Province has got a new force in the development of new energy industry. In the new energy development, not only solar photovoltaic cells, solar wafers, wind blade production has been among the domestic front, but also has been an important photovoltaic cell domestic manufacturing base. At the same time, the rapid development of new energy industry will also have a great impact on the economic structure of Hebei Province in future [1].

\section{ANALYSIS ON THE CURRENT SITUATION OF NONRENEWABLE ENERGY RESOURCES IN HEBEI PROVINCE}

\section{A. The Petroleum and Petrochemical Energy}

Since 1980, the energy consumption in Hebei Province continues to rising, the average growth rate of annual energy consumption during 1980-2013 was 7.5\%. The development of energy consumption has experienced two stages. The first stage is 1980-1999 years, with an average annual growth rate of $5.97 \%$. The second stage is 2000-2013 years, with the average annual growth rate of $10.48 \%$. The stage division of energy consumption in Hebei Province is strongly associated with economic growth. From 1980 to 2013, the correlation coefficient between GDP and energy consumption in Hebei Province was 0.993. According to the 1980 constant prices, the average growth rate of economy in Hebei Province during $1980-1999$ was $7.14 \%$, compared with $11.20 \%$ in 2000 2013 [2, 3].

\section{B. Coal Resources}

The coal range is from lignite to anthracite. Hebei Province has long flame coal, fat coal, coking coal and also has the power and civil coal. The Carboniferous Permian coal that anthracite part is generally about 20$25 \%$, sulfur content in Benxi group and Taiyuan group coal is higher. The province's total proven reserves are 165.6 tons, the remaining recoverable reserves are 36.8 tons, the economic recoverable reserves are 22 tons (see Table I) [3, 4], of which coking coal resources reserves accounted by $60 \%$.

TABLE I. CoAl Reserves of HeBei PRovince IN 2013.

\begin{tabular}{|c|c|c|c|c|}
\hline $\begin{array}{c}\text { Mineral } \\
\text { Resources }\end{array}$ & Type & Unit & $\begin{array}{c}\text { At the Beginning of } \\
\text { the Year }\end{array}$ & $\begin{array}{c}\text { At the End of } \\
\text { the Year }\end{array}$ \\
\hline \multirow{3}{*}{ Coal } & Basic reserves & $\begin{array}{c}\text { Thousand } \\
\text { tons }\end{array}$ & 11357940.65 & 11546707.2 \\
\cline { 2 - 5 } & The amount & $\begin{array}{c}\text { Thousand } \\
\text { tons }\end{array}$ & 10136905.56 & 11310877.9 \\
\cline { 2 - 5 } & $\begin{array}{c}\text { Resources and } \\
\text { reserves }\end{array}$ & $\begin{array}{c}\text { Thousand } \\
\text { tons }\end{array}$ & 21494846.21 & 22857585 \\
\hline
\end{tabular}

Hebei Province has long been the overload in the excess production. The coal industry is in imbalance state, which resulting in at least two very serious consequences:
One is the production of enterprises want to improve the output of coal in the mining, so they reduce the rate of extraction in the mine, waste a lot of valuable resources, 
especially the township and private coal mine is more serious; Two is the coal overdraft brings a great security risk, which is one of the main reasons of coal mine safety accidents in recent years. Coal output and profit of Hebei Province in 2013 are shown in following Table II:

TABLE II. CoAl OUtput AND Profit of Hebei Province IN 2013.

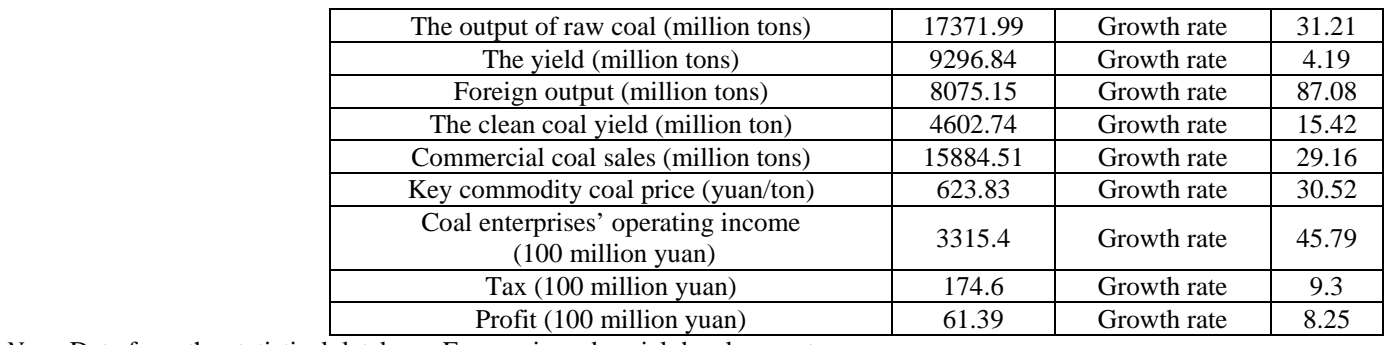

Note: Data from the statistical database: Economic and social development.

Coal consumption and energy consumption are the same trend in Hebei Province. Coal consumption accounted for the total energy consumption was always $90 \%$ except for a few years, the ratio continued to rise since 2000, rise up to $92.51 \%$ in 2009. Therefore, the energy consumption structure of Hebei Province has brought great pressure to the work of energy-saving and emission reduction.

\section{Iron ore resources}

Iron mine in Hebei Province is one of a large area of China's reserves. By the end of 2010, Hebei Province has identified reserves of iron ore resources was 85.43 tons, accounting for $11.82 \%$ of the national total, ranking the third in the whole country. The regional distribution of exploration iron ore resources on the table (which has been approved by the national reserves management department) has 246. In the mineral table on 246, large at 11 , medium size were 99, small were 136 . Had used the 197 areas, accounting for $80.08 \%$, reserves of 46.12 tons, accounting for the province's resources reserves of $63.62 \%$; the number of unused areas were 49 , which resource reserves were 26.38 tons, accounting for the province's resources reserves was $36.38 \%$. Manufacturers are mainly Tangshan iron and steel, Handan iron and steel, and the capital iron and steel company. Hebei Province has almost all types of iron ore resources, but the distribution is not uniform, Shijiazhuang accounted for only $0.04 \%$, while Tangshan accounted for $75.88 \%$ [4], Cangzhou, Langfang, Hengshui cities are rarely (Table III).

TABLE III. IRON ORE RESERVES OF HeBei Province IN 2013.

\begin{tabular}{|c|c|c|c|c|}
\hline Mineral & Type & Unit & $\begin{array}{c}\text { At the Beginning } \\
\text { of the Year }\end{array}$ & $\begin{array}{c}\text { At the End of } \\
\text { the Year }\end{array}$ \\
\hline \multirow{3}{*}{ Iron ore } & $\begin{array}{c}\text { Basic } \\
\text { reserves }\end{array}$ & $\begin{array}{c}\text { Thousand } \\
\text { tons }\end{array}$ & 10272361.94 & 11073681.1 \\
\cline { 2 - 5 } & The amount & $\begin{array}{c}\text { Thousand } \\
\text { tons }\end{array}$ & 2411230.5 & 2634757.72 \\
\cline { 2 - 5 } & $\begin{array}{c}\text { Resources } \\
\text { and reserves }\end{array}$ & $\begin{array}{c}\text { Thousand } \\
\text { tons }\end{array}$ & 12683592.44 & 13708438.8 \\
\hline
\end{tabular}

\section{ANALYSIS ON RENEWABLE ENERGY RESOURCES IN HeBei PROVINCE}

\section{A. Solar Energy Resources}

Total annual solar radiation in Hebei Province are 5 billion joules/square meters, which is much higher than anywhere else except western provinces. At present, the solar cell products from Hebei has been used by China's remote western villages without power, Dunhuang village, the ancient "Silk Road" and mountains, islands, and both sides of the highway with light and energy release; polycrystalline silicon solar energy application field of Hebei Province has also made some progress. Only in the case of Baoding, solar wafers, cells and modules outputs in 2013 accounted for $15.7 \%$ of the national total, ranking the second in the country, wind blade production accounted for $40 \%$ of the domestic market, ranking first in the country.

\section{B. Wind Energy Resources}

The total wind energy resource reserves in Hebei Province are 74 million kilowatts, the amount that technology could explore in land are more than 17 million kilowatts, the amount that technology could explore offshore are exceeding 4 million kilowatts. The main distribution area are in Zhangjiakou, Chengde dam, Qinhuangdao, Tangshan, Cangzhou and Taihang Mountain coastal area, Yanshan mountain area. At present, there are more than 30 companies in Bashang of Hebei Province and the coastal wind farms to carry out preliminary work, among them, the construction investment company of Hebei Province installed capacity of 1380000 kilowatts, come out in front in the same company in the nation.

\section{Biomass Energy}

Hebei Province is a big agricultural province. The annual output of all kinds of crops straw is about 36 million tons, remove the use for firewood, returning, aquaculture, paper-making, the remaining amount of waste straw is more than 12 million tons. The province's forest area is 
about 71 million mu, 21 million mu of forest resources can be used as energy, the amount of tree branches can be used is about 2 million tons.

\section{Hydropower and Geothermal Energy}

The water resources in Hebei Province are extremely deficient, which average annual precipitation is $540 \mathrm{~mm}$, ranked twenty-third in the country. An average of surface water resources is about 152 billion $\mathrm{m}^{3}$, ranking the twenty-fifth in the country.

According to the national science and technology key project: "evaluation on water resources in North China and the exploitation and utilization" and "evaluation on groundwater resources in North China” provided the data about fresh water resources, water area of Hebei Province is less, per capita, Baoding city and Shijiazhuang city are comparably higher, other city are lower than the average level. The recoverable amount of the geothermal resources in Hebei Province is equivalent to 94 tons of standard coal. The renewable energy resources and development status in Hebei Province are shown in Table IV.

TABLE IV. THE RENEWABLE ENERGY RESOURCES AND DEVELOPMENT STATUS.

\begin{tabular}{|c|c|c|}
\hline \multirow{2}{*}{$\begin{array}{c}\text { Wind } \\
\text { energy }\end{array}$} & Total reserves (kw) & 7400 \\
\cline { 2 - 3 } & The amount that can be developed (kw) & 1700 \\
\cline { 2 - 3 } & The total installed capacity (MW) & 2802 \\
\hline \multirow{2}{*}{$\begin{array}{c}\text { Biomass } \\
\text { energy }\end{array}$} & The annual output (10000 tons) & 3600 \\
\cline { 2 - 3 } & The total installed capacity (MW) & 224 \\
\hline \multirow{2}{*}{$\begin{array}{c}\text { Solar } \\
\text { energy }\end{array}$} & Annual sunshine hours (hour) & $3000-3200$ \\
\cline { 2 - 3 } & $\begin{array}{c}\text { Solar water heater area } \\
\text { (million square meters) }\end{array}$ & 450 \\
\hline \multirow{2}{*}{$\begin{array}{c}\text { Hydropower } \\
\text { energy }\end{array}$} & $\begin{array}{c}\text { The quantity of water resources } \\
\text { (billion cubic meters) }\end{array}$ & 205 \\
\cline { 2 - 3 } & The total installed capacity (MW) & 179 \\
\hline $\begin{array}{c}\text { Geothermal } \\
\text { energy }\end{array}$ & Geothermal resources (tons) & 94 \\
\cline { 2 - 3 } & Geothermal plant (hectare) & 156 \\
\hline
\end{tabular}

\section{COUNTERMEASURES OF DEVELOPING LOW CARBON ECONOMY IN HEBEI PROVINCE}

\section{A. Accelerate the Pace of Industrial Structure Adjustment}

Hebei Province's industrial structure is in the fourth layer in the domestic industry division, which featured high energy consumption, high water consumption and typical low value added industries. (The added value accounted for the industrial added value of steel, textile, oil processing, chemical, pharmaceutical, building materials, food these seven industries reached to $80.5 \%$, the growth rate of industrial production and the contribution rate were $87.1 \%)$. The industrial structure of Hebei is a "two three one" mode, the structure of employment is "one two three" mode.

Heavy chemical industry is an important pillar of economic and social development in Hebei Province. The development of low carbon economy does not mean that will limit the development of heavy chemical industry, but by the use of low carbon technology and promoting the adjustment of industrial structure to gradually establish a development mode with low energy consumption, low material requirements and low carbon emissions of modern industrial system [5]. At the same time, by positive develop the high and new technology industries and modern service industry, we can use high technology to transform the iron and steel, cement and other traditional industries which were the type of high energy consumption and high emission, finally to reduce the carbon intensity of GDP.

\section{B. Vigorously Promote Technology Innovation on Energy and Emission Reduction}

In the aspects of low carbon technology development and application, Hebei Province must be supported by technical innovation, to speed up the production technology and improvement of the production mode of operation, to improve the energy efficiency of the product, and realize economic development and carbon emissions "decoupling." To establish science and technology innovation service system for the development of low carbon economy, intensify the major energy technology development and industrialization support, encourage relying on scientific research units and enterprises to advance energy-saving technology development and efficient energy-saving equipment, and introduce competition mechanism to the implementation of market-oriented operation.

\section{Improve the Supporting Policies}

Hebei Province should promote urban heating price reform according to the use of heat metering and charging, improve the sewage charges and garbage disposal fee system, and reasonable improve collection standards. To establish provincial special funds for energy saving and encourage the production to use the products listed in the catalogues of tax policy. To implement water pricing ladder as soon as possible. Study to establish financial subsidy mechanism to the amount of energy saving products that widely be used. Study on the implementation of compulsory procurement of energy-saving products. To broaden the financing channels, to promote domestic and international financial institutions' funds and foreign government loans are inclined to the field of energy saving and emission reduction.

\section{Promote "Low-carbon" Mode}

To take a variety of forms for regular, thematic, three-dimensional publicity education, make low carbon consciousness win support among the people. Give full play to the exemplary role in the management process of government and public administration in the low carbon economy and social development. Make the "low carbon" as an important content in the construction of a conservable oriented government, improving management efficiency and service quality. Government and public administration should take the lead in the use of energy saving office building, the implementation of paperless in office, and the "low carbon" government procurement. Should advocate saving and civilized way of life in the whole of society. Promote "low carbon" mode on eating, 
wearing, using, housing and other fields. To carry out classification of garbage collection, saving water and energy, advocating low carbon consumption, carrying out the "low carbon office," "low carbon community" and other activities to create a good social atmosphere, to finally promote the formation of low carbon economy.

\section{ACKNOWLEDGMENTS}

The research work was supported by Soft Science Project of Hebei Provincial under Grant No. 14457688D and Grant No. 12457206D-8 and Grant No. 13454215D.

\section{REFERENCES}

[1] Cai Xinlei, The relationship between energy consumption and GDP in our country - based on empirical analysis of the time series. Journal of Economic Issues, 2010.

[2] Chen Yingzi, Li Yutong, Research on low-carbon economy and regional energy utilization in China. Journal of Social Sciences of Jilin University, 2009.

[3] Hebei Province Statistical Bureau. Hebei Statistical Yearbook (2012). China Statistics Press, 2013.

[4] Hebei Province Statistical Bureau. Hebei Energy Bulletin. China Statistics Press, 2013.

[5] Hebei Province's development and reform commission, The 12th Five-year Plan of Hebei Province (2011-2015), 2011. 